\title{
Perbedaan Kadar LDL-kolesterol pada Pasien Diabetes Melitus Tipe 2 dengan dan tanpa Hipertensi di RS Dr. M. Djamil Padang Tahun 2011
}

\author{
Finisia Noviyanti ${ }^{1}$, Eva Decroli ${ }^{2}$, Susila Sastri ${ }^{3}$
}

\begin{abstract}
Abstrak
Hipertensi seringkali menjadi kondisi komorbid yang menyertai diabetes melitus tipe 2. Diabetes melitus, hipertensi dan peningkatan LDL kolesterol merupakan keadaan yang sering dijumpai saling berkaitan. Tujuan penelitian ini adalah untuk melihat perbedaan kadar LDL kolesterol penderita diabetes melitus tipe 2 dengan dan tanpa hipertensi. Penelitian ini menggunakan desain cross sectional comparatif. Pengumpulan data dilakukan dengan observasi data rekam medis pasien diabetes melitus tipe 2 dengan dan tanpa hipertensi tahun 2011 di RS. Dr. M. Djamil Padang. Analisis statistik menggunakan uji chi-square dan uji t-berpasangan. Hasil penelitian menemukan kadar LDL kolesterol pada pasien diabetes melitus tipe 2 dengan hipertensi $(137,56 \pm 41,43 \mathrm{mg} / \mathrm{dl})$ lebih tinggi dibandingkan tanpa hipertensi $(94,39 \pm 35,36 \mathrm{mg} / \mathrm{dl})$. Uji chi-square menunjukkkan adanya hubungan yang bermakna antara peningkatan kadar LDL kolesterol dengan kejadian hipertensi $(p<0,05)$. Uji t-berpasangan menunjukkan bahwa adanya perbedaan bermakna kadar LDL kolesterol antara kelompok pasien diabetes melitus dengan hipertensi dan tanpa hipertensi $(p<0,05)$. Penelitian ini menyimpulkan adanya perbedaan yang bermakna kadar LDL kolesterol pada pasien diabetes melitus tipe 2 dengan hipertensi dan tanpa hipertensi di RS. Dr. M. Djamil Padang.
\end{abstract}

Kata kunci: LDL kolesterol, diabetes melitus tipe 2, hipertensi

\begin{abstract}
Hypertension is often a comorbid conditions that accompany diabetes mellitus type 2. Diabetes mellitus, hypertension and increased LDL cholesterol is a condition that is often be found related one another. The objective of this study was to determine difference $L D L$ cholesterol level among diabetes melitus type 2 with hypertension and without hypertension. This research used cross-sectional comparatif design. The data was collected through observation of the patient's medical records diabetes mellitus type 2 with hypertension and without hypertension in 2011 at the hospital Dr. M. Djamil Padang. The statistical analysis used was chi-square test and paired-T test. The results found that the levels of LDL cholesterol in patients with diabetes mellitus type 2 with hypertension $(137,56 \pm 41,43)$ was higher than without hypertension $(94,39 \pm 35,36)$. Chi square test was found that a significant correlation between elevates levels of $L D L$ cholesterol to the incidence of hypertension $(p<0,05)$. Paired-t test showed that there were significant differences of LDL cholesterol levels between groups of diabetes mellitus type 2 with hypertension and diabetes mellitus type 2 without hypertension $(p<0,05)$. This research conclude that there are differences in the levels of LDL cholesterol in patients with diabetes melitus type 2 with hypertension and without hypertension in the hospital Dr. M. Djamil Padang in 2011.
\end{abstract}

Keywords: LDL cholesterol, diabetes mellitus type 2, hypertension

Affiliasi penulis: 1. Pendidikan Dokter FK UNAND (Fakultas Kedokteran Universitas Andalas Padang), 2. Bagian IImu Penyakit Dalam FK UNAND/RS Dr. M. Djamil Padang 3. Bagian Biokimia FK UNAND

Korespondensi: Finisia Noviyanti, E-mail:

finisia_noviyanti@yahool.com, Telp: 087895170295 


\section{PENDAHULUAN}

Diabetes melitus merupakan penyakit degeneratif yang mengalami peningkatan dari tahun ke tahun. Penelitian epidemiologi yang dilakukan sampai tahun 2005, prevalensi diabetes melitus di Jakarta pada tahun 1982 sebesar 1,6\%, tahun 1995 sebesar 5,7\% dan tahun 2005 sebesar 14,7\%. ${ }^{1}$

Sama halnya dengan di Jakarta, prevalensi diabetes melitus di kota Padang juga selalu mengalami peningkatan. Diabetes melitus menempati urutan pertama dari seluruh penyakit endokrin. Peningkatan prevalensi diabetes melitus dikaitkan dengan peningkatan kemakmuran suatu populasi secara global, sehingga diabetes melitus banyak mendapat sorotan. ${ }^{1}$

Bukti epidemiologi menunjukkan bahwa populasi dengan diabetes melitus memiliki risiko terjadinya penyakit kardiovaskular dua sampai lima kali dibandingkan populasi tanpa diabetes melitus. ${ }^{2}$ Dilaporkan angka kesakitan dan kematian akibat diabetes melitus di Indonesia cenderung berfluktuasi naik setiap tahunnya. Di kota Padang, diabetes melitus merupakan penyebab kematian nomor 4 setelah ketuaan, korban gempa dan penyakit jantung. ${ }^{3}$

Pada diabetes melitus tipe 2 (DMT2) terjadi kelainan metabolisme karena resistensi insulin yang mempengaruhi metabolisme dalam tubuh diantaranya terjadi perubahan proses produksi dan pembuangan lipoprotein plasma. $^{4} \mathrm{Di}$ jaringan lemak terjadi penurunan efek insulin sehingga lipogenesis berkurang dan lipolisis meningkat. ${ }^{5} \mathrm{Hal}$ ini akan memicu terjadinya glucotoxicity disertai lipotoxicity yang menyebabkan terjadinya peningkatan kadar LDL kolesterol. $^{6}$ Dalam keadaan hipergikemia, oksidasi LDL berlangsung lebih cepat. ${ }^{5} \mathrm{Hal}$ ini diakibatkan oleh peningkatan kadar glukosa darah kronis. Pada pasien DMT2 yang tidak terkontrol, terjadinya glikasi LDL lebih cepat. $^{7}$ Struktur LDL pada DMT2 menjadi termodifikasi; teroksidasi; glikasi; menjadi kecil dan padat sehingga makin bersifat aterogenik. ${ }^{8}$

Low Density Lipoprotein-kolesterol (LDL-kol) merupakan lipoprotein yang berperan dalam pengangkutan fraksi lemak, terutama kolesterol dari hati menuju ke sel perifer. ${ }^{9}$ LDL-kol memiliki inti hidrofobik mengandung koleterol ester (35\%-40\%) paling banyak daripada lipoprotein lain. ${ }^{10}$ Peningkatan kadar LDL-kol plasma merupakan penyebab utama pembentukan plak aterosklerosis terutama dalam bentuk oksidasi LDL (Ox-LDL). Peningkatan kadar LDL-kolesterol dalam darah merupakan salah satu penyebab terjadinya gangguan kesehatan terutama gangguan kardiovaskuler dan aterosklerotik. ${ }^{11}$

Resistensi insulin pada DMT2 meningkatkan lipolisis pada jaringan adiposa sehingga terjadi peningkatan lemak dalam darah termasuk kolesterol dan trigliserida. ${ }^{12}$ Hiperkolesterolemia akan memicu peningkatan LDL-kol dan penurunan kadar HDLkolesterol. Ketiga fraksi lipid tersebut disebut dengan triad lipid yang berperan penting dalam proses terjadinya aterosklerosis. Keadaan ini dikenal sebagai dislipidemia. ${ }^{10}$ Selain dislipidemia, terdapat beberapa keadaan lain yang berperan dalam terjadinya peningkatan LDL-kol antara lain diabetes melitus dan hipertensi. $^{13}$

Hipertensi merupakan salah satu masalah kesehatan lain yang prevalensinya tinggi dan terus meningkat dari tahun ke tahun. Prevalensi hipertensi di Sumbar sendiri mencapai 31,2\% dan kota Padang tercatat menyumbang sebesar $26 \%$. Berdasarkan laporan tahunan Dinas Kesehatan Kota Padang tahun 2009, hipertensi dilaporkan sebagai 10 penyakit terbanyak di Kota Padang dengan jumlah sebanyak 36.456 kasus hipertensi atau sebesar $8,1 \%$ dan merupakan penyebab kematian nomor 5 setelah ketuaan, korban gempa, penyakit jantung dan diabetes melitus. ${ }^{3}$ Pada laporan tahunan Dinas Kesehatan Kota Padang 2010, hipertensi juga dinyatakan sebagai lima penyakit tidak menular utama. $^{14}$

Hipertensi adalah suatu keadaan peningkatan tekanan darah sistolik lebih besar dari $140 \mathrm{mmHg}$ dan/atau diastolik lebih besar dari $90 \mathrm{mmHg}$. Hipertensi merupakan salah satu penyebab lain timbulnya penyakit kardiovaskuler seperti serangan jantung, gagal jantung, dan stroke. Hipertensi memiliki pengaruh terhadap terjadinya proses aterosklerosis, namun sering diabaikan karena penyakit ini tidak menunjukkan gejala yang dapat dilihat dari luar sehingga disebut the silent killer. ${ }^{15}$

Proses aterosklerosis yang terjadi secara keseluruhan pada kondisi hipertensi merupakan proses terjadinya kelainan vaskuler yang terjadi 
melalui banyak tahapan yang berawal dari kerusakan endotel dan akumulasi LDL-kol, kemudian berlanjut dengan terjadinya plak pada pembuluh darah. Akibatnya, terjadinya peningkatan resistensi perifer sehingga tekanan darah akan menjadi meningkat. Hal ini menjelaskan terdapat kaitan erat antara peran LDLkol terhadap aterosklerosis dengan meningkatnya tekanan darah. ${ }^{8}$

Diabetes melitus, hipertensi dan peningkatan LDL-kol merupakan keadaan yang sering dijumpai saling berkaitan. Hipertensi dan peningkatan LDL kolesterol bisa menjadi kondisi komorbiditas yang menyertai diabetes melitus. ${ }^{11}$ Diabetes melitus dan hipertensi yang terjadi secara terpisah berpengaruh terhadap peningkatan LDL kolesterol lebih rendah dibandingkan ketika kedua kondisi tersebut terjadi secara bersamaan. ${ }^{16}$ Hal ini akan sebanding dengan semakin besarnya risiko terjadinya penyakit kardiovaskuler dan aterosklerotik. ${ }^{8} \quad$ Munculnya diabetes melitus yang disertai dengan hipertensi akan mempercepat munculnya komplikasi makro dan mikrovaskuler pada diabetes melitus. ${ }^{11}$ Komplikasi vaskuler yang terjadi pada dasarnya saling berkaitan satu sama lain dan akan menjadi suatu lingkaran setan yang sulit untuk diobati. ${ }^{13}$

Walaupun sebagian besar literatur epidemiologi menemukan bukti adanya korelasi positif antara peningkatan kadar LDL kolesterol dengan hipertensi pada pasien DMT2, hubungan ketiga kondisi ini masih belum banyak dilakukan di kota Padang, khususnya di RS Dr. M. Djamil Padang.

Tujuan penelitian ini adalah untuk mengetahui apakah terdapat perbedaan kadar LDL kolesterol pada pasien diabetes melitus dengan hipertensi dan tanpa hipertensi.

\section{METODE}

Penelitian dilakukan di Sub.bagian Rekam Medik RS Dr. M. Djamil Padang. Pelaksanaan penelitian dari Januari 2012 - Maret 2013. Data diperoleh dari rekam medik pasien yang didiagnosis DMT2 dengan hipertensi dan tanpa hipertensi dan telah melakukan pemeriksaan kadar LDL kolesterol di RSUP Dr. M. Djamil tahun 2011. Data tersebut merupakan hasil dari pemeriksaan klinis dan laboratorium, yang dilakukan oleh dokter yang berkompeten. Penelitian ini menggunakan desain cross sectional comparatif dengan jumlah data rekam medik sebanyak 152 yang dibagi menjadi dua kelompok yaitu kelompok DMT2 dengan hipertensi dan kelompok DMT2 tanpa hipertensi dengan jumlah masing-masing 76 pasien. data yang diperoleh kemudian diolah secara statistik Analisis statistik yang digunakan adalah uji chi-square dan uji t-berpasangan dengan tingkat pemaknaan $p<0,05$.

Hasil

Tabel 1. Distribusi frekuensi pasien DMT2 menurut umur dan jenis kelamin, dengan dan tanpa hipertensi di RS. Dr. M. Djamil Padang

\begin{tabular}{ccccc}
\hline $\begin{array}{c}\text { Umur } \\
\text { (tahun) }\end{array}$ & \multicolumn{3}{c}{ DMT2 } \\
\hline & $\mathrm{N}$ & $\%$ & $\mathrm{~N}$ & $\%$ \\
\hline$<30$ & 0 & 0,0 & 0 & 0,0 \\
$30-39$ & 9 & 5,69 & 3 & 1,97 \\
$40-49$ & 14 & 8,86 & 18 & 11,39 \\
$50-59$ & 19 & 12,5 & 50 & 32,89 \\
$60-69$ & 11 & 6,96 & 21 & 13,81 \\
$>70$ & 3 & 1,89 & 4 & 2,53 \\
\hline Jumlah & 56 & 36,84 & 96 & 63,16 \\
\hline
\end{tabular}

Tabel 1 memperlihatkan dari 152 orang pasien yang terdiagnosis DMT2 didapatkan banyak diderita wanita $(63,16 \%)$ dibanding pria $(36,84 \%)$. Sebaran penderita DMT2 terbanyak pada umur 50-59 tahun. Umur penderita termuda adalah 30 tahun dan yang tertua adalah 80 tahun.

Tabel 2. Distribusi frekuensi kadar LDL kolesterol serum pada pasien DMT2 di RS. Dr. M. Djamil Padang

\begin{tabular}{ccc}
\hline Kadar LDL-Kol & $\mathbf{N}$ & $\%$ \\
\hline Normal & 61 & 40,1 \\
Tinggi & 91 & 59,9 \\
\hline Total & 152 & 100 \\
\hline
\end{tabular}

Tabel 2 menunjukkan 59,9\% pasien DMT2 memiliki kadar LDL-kol tinggi dari normal dan 40,1\% pasien diabetes melitus dengan kadar LDL-kol dalam batas normal. 
Tabel 3. Distribusi frekuensi, rerata dan standar deviasi tekanan darah pada pasien DMT2 $(\mathrm{mmHg})$

\begin{tabular}{|c|c|c|c|}
\hline Kelompok & $\mathbf{n}$ & Mean & SD \\
\hline Hipertensi & & 76 & \\
\hline TDS & & 157,5 & 17,21 \\
\hline TDD & & 91,47 & 11,51 \\
\hline Tidak Hipertensi & & 76 & \\
\hline TDS & & 119,74 & 10,70 \\
\hline TDD & & 75,79 & 8,2 \\
\hline
\end{tabular}

Ket : TDS=Tekanan Darah Sistolik, TDD $=$ Tekanan Darah Diastolik, $\mathrm{f}_{=}$ frekuensi, $\mathrm{SD}=$ Standar Deviasi

Berdasarkan Tabel 3 dapat dilihat bahwa rerata tekanan darah sistolik (TDS) pada kelompok hipertensi adalah $157,5 \pm 17,21 \mathrm{mmHg}$ dan rerata tekanan darah diastolik (TDD) adalah 91,47 $\pm 11,51 \mathrm{mmHg}$. Pada kelompok tidak hipertensi, hasil pengukuran tekanan darah menunjukkan rerata tekanan darah sistolik adalah $119,74 \pm 10,7 \mathrm{mmHg}$ dan rrata tekanan darah diastolik adalah $75,79 \pm 8,2 \mathrm{mmHg}$. Rerata tekanan darah pada penderita DMT2 dengan hipertensi merupakan kategori hipertensi derajat satu.

Tabel 4. Perbandingan distribusi frekuensi kadar LDL kolesterol pada pasien DMT2 dengan dan tanpa hipertensi di RS. Dr. M. Djamil Padang

\begin{tabular}{cccc}
\hline $\begin{array}{c}\text { Pasien } \\
\text { DMT2 }\end{array}$ & $\mathbf{N}$ & $\begin{array}{c}\text { LDL } \\
\text { Kolesterol } \\
(\mathbf{m g} / \mathbf{d l})\end{array}$ & $\mathbf{p}$ \\
\hline $\begin{array}{c}\text { Dengan } \\
\text { Hipertensi }\end{array}$ & 76 & $137,56 \pm 41,43$ & \\
$\begin{array}{c}\text { Tanpa } \\
\text { Hipertensi }\end{array}$ & 76 & $94,39 \pm 35,36$ & $0,026^{*}$ \\
\hline
\end{tabular}

Tabel 4 menjelaskan bahwa rerata kadar LDLkol tinggi terdapat pada pasien DMT2 dengan hipertensi, sedangkan kadar LDL kolesterol normal rata-rata terdapat pada DMT2 tanpa hipertensi.

Tabel 5 memperlihatkan bahwa kadar LDL kolesterol pada pasien DMT2 dengan hipertensi lebih tinggi dibandingkan DMT2 tanpa hipertensi. Berdasarkan uji chi-square yang dilakukan, maka diperoleh nilai $p=0,00$. Dapat disimpulkan bahwa terdapat hubungan bermakna antara kadar LDL kolesterol dengan kejadian hipertensi pada pasien DMT2 $(p<0,05)$.
Tabel 5. Kadar LDL-kolesterol darah dengan dan tanpa hipertensi pada pasien DMT2

\begin{tabular}{|c|c|c|c|}
\hline \multirow[t]{2}{*}{ Pasien DMT2 } & \multicolumn{2}{|c|}{$\begin{array}{c}\text { Kadar LDL-Kolesterol } \\
\text { (mg/dl) }\end{array}$} & \multirow[t]{2}{*}{ Tota } \\
\hline & Normal & Tinggi & \\
\hline Tidak Hipertensi & 49 & 27 & 76 \\
\hline Hipertensi & 12 & 64 & 76 \\
\hline Total & 61 & 91 & 152 \\
\hline
\end{tabular}

Tabel 6 menunjukkan bahwa kadar LDL kolesterol pada kelompok DMT2 dengan hipertensi lebih tinggi dibandingkan pada kelompok tanpa hipertensi. Secara statistik dengan uji t-paired didapatkan adanya perbedaan bermakna kadar LDLkol antara kelompok pasien DMT2 dengan hipertensi dan tanpa hipertensi dengan nilai $p=0,026(p<0,05)$.

Tabel 6. Perbandingan kadar LDL kolesterol pada pasien DMT2 dengan dan tanpa hipertensi

\begin{tabular}{ccccc}
\hline $\begin{array}{c}\text { Kadar LDL } \\
\text { Kolesterol } \\
(\mathbf{m g} / \mathbf{m l})\end{array}$ & \multicolumn{5}{c}{ Hipertensi } & \multicolumn{3}{c}{ Tidak Hipertensi } \\
& N & $\%$ & N & $\%$ \\
\hline Normal & 12 & 15,79 & 49 & 64,47 \\
Tinggi & 64 & 84,21 & 27 & 35,53 \\
\hline Total & 76 & 100 & 76 & 100 \\
\hline
\end{tabular}

\section{DISKUSI}

Hasil penelitian di atas sejalan dengan hasil penelitian yang dilakukan oleh Glaudio et al di Italy. ${ }^{17}$ Hasil penelitiannya menunjukkan bahwa terdapat hubungan yang signifikan antara tekanan darah dengan kadar LDL kolesterol dengan nilai $p<0,02$.

Penelitian Siregar yang dilakukan di RSUP H. Adam Malik Medan juga menunjukkan bahwa pada pemeriksaan LDL-kol pada kelompok DMT2 dengan hipertensi didapatkan rerata kadar LDL-kol lebih tinggi dibandingkan pada kelompok non hipertensi dan secara statistik dijumpai perbedaan bermakna dengan nilai $p=0,001 .^{4}$ Wijaya yang melakukan penelitian di RSUD dr. Moewardi Surakarta pada Mei-April 2010 juga menunjukkan hasil yang sama. Pada penelitian tersebut disimpulkan adanya peningkatan rerata kadar 
LDL-kol pada DMT2 dengan hipertensi dibandingkan dengan tanpa hipertensi. ${ }^{20} \mathrm{Hal}$ ini juga sejalan dengan yang dinyatakan oleh Isezuo dan Ezunu bahwa DMT2 dan hipertensi yang terjadi secara terpisah tidak mengakibatkan peningkatan LDL-kol lebih rendah dibandingkan ketika kedua kondisi tersebut terjadi bersamaan. $^{16}$

Idogun et al juga telah melakukan penelitian terhadap 52 subyek DMT2 yaitu 16 orang diabetes melitus dengan hipertensi, 23 orang diabetes melitus tanpa hipertensi dan 13 orang diabetes melitus dengan nefropati. Hasil penelitian ini menunjukkan hal yag sama, bahwa terdapat perbedaan yang bermakna antara LDL kolesterol dengan kejadian hipertensi pada populasi DMT2 dengan nilai $p<0,0001 .^{18}$

Sesuai dengan hasil penelitian, kadar LDL-kol semakin meningkat pada pasien DMT2 jika disertai dengan hipertensi. Menurut para ahli, selain karena keadaan resistensi insulin yang terjadi pada pasien DMT2, peningkatan LDL-kol akan semakin memburuk akibat adanya proses disfungsi endotel akibat hipertensi. Tekanan darah yang tinggi menyebabkan jantung memompa lebih kuat. Aliran darah yang lebih kuat ini akan menghantam pembuluh darah sehingga elastisitas pembuluh darah menjadi lemah. Hal ini akan memicu LDL teroksidasi ataupun small dense terkumpul dalam dinding endotel arteri sehingga terjadi peningkatan kadar LDL kolesterol dalam serum. $^{20}$

\section{KESIMPULAN}

Terdapat perbedaan kadar LDL-kolesterol pada DMT2 dengan hipertensi yang bermakna jika dibandingkan dengan DMT2 tanpa hipertensi.

DMT2 lebih banyak diderita wanita dibanding pria, baik DMT2 dengan hipertensi maupun tanpa hipertensi. Sedangkan berdasarkan umur, sebaran penderita DMT2 terbanyak pada umur 50-59 tahun.

Rerata kadar LDL kolesterol pada pasien DMT2 dengan hipertensi lebih tinggi dibandingkan DMT2 tanpa hipertensi.

Rerata LDL-kol tinggi terdapat pada pasien DMT2 dengan hipertensi, sedangkan rerata kadar LDL kolesterol normal terdapat pada pasien DM 2 tanpa hipertensi.
Adanya hubungan antara peningkatan kadar LDL-kolesterol dengan kejadian hipertensi pada pasien DMT2 $(p<0,05)$.

\section{DAFTAR PUSTAKA}

1. Suyono S. Diabetes melitus di Indonesia. Dalam: Buku Ajar Ilmu Penyakit Dalam. Interna Publishing.; 2009.

2. Mshelia DS. The Usefullness of total cholesterol and high density lipoprotein cholesterol ratio in interpretating lipid profile results of diabetes mellitus patients. Nigerian Journal of Clinical Practice. 2009:345-9.

3. Dinas Kesehatan Kota Padang, Laporan Tahunan Tahun 2009. hlm.137.

4. Siregar J. Perbandingan kadar LDL kolesterol pada Diabetes Mellitus dengan atau tanpa hipertensi. (tesis). Medan: Universitas Sumatera Utara; 2010.16-7.

5. Syahbuddin S. Aterosklerosis pada diabetes mellitus : peran dislipidemia. Dalam: Naskah Lengkap Pertemuan IImiah Berkala-II IImu Penyakit Dalam Fakultas Kedokteran Universitas Andalas, Padang; 2001.hlm.72-7.

6. Manaf A. Chronic and acute postprandial hyperglicemia with stress oxidative : the background of tissue damage in type 2 diabetes melitus. Dalam: Naskah lengkap PIB VIII IImu Penyakit Dalam FK Unand RSUP M. Djamil, Padang; 2007.

7. Marks DB, Marks AD, Smith CM. Metabolisme Kolesterol dan Lipoprotein Darah. Dalam: Suyono J, Sadikin V, Mandera L, editor peterjemah. Basic Medical Biochemistry: A clinical Approach. Jakarta: EGC; 2000.

8. Waspadji S. Paradigma baru pengelolaan dislipidemia : penekanan pada peran HDL. Dalam: Naskah Lengkap PIB VII IImu Penyakit Dalam FK Unand RSUP M. Djamil Padang; 2006.

9. Pusparini. Low density lipoprotein padat kecil sebagai faktor risiko aterosklerosis. Dalam: Majalah Universa Medicina. 2006;25(1):22-31.

10. Adam JMF. Dislipidemia. Dalam: Sudoyo AW, Setiyohadi B, Alwi I, Simadibrata KM, Setiati S. editor (penyunting). Buku Ajar IImu Penyakit Dalam 
Jilid III. Edisi ke-5 Jakarta: Interna Publishing; 2009.hlm.1984-6.

11. Decroli E. Penatalaksanaan hipertensi pada diabetes. Dalam: Naskah Lengkap PIB IX IImu Penyakit Dalam FK Unand RSUP M. Djamil: Padang; 2008.

12. Rader DJ, Hoobs HH. Disorders of lipoprotein metabolism. Dalam: Harrison's Principles of Internal Medicine. Edisi ke-16. New York: Mc Graw Hill; 2005. 2286-98.

13. Carleton FP, Marjorie BA. Penyakit aterosklerotik koroner. Dalam: Price SA, Wilson LM, editor (penyunting). Patofisiologi Konsep klinis Prosesproses Penyakit. Jakarta: EGC; 2006. 531.

14. Dinas Kesehatan Kota Padang, Laporan Tahunan Tahun 2010 Edisi 2011. Padang.

15. Hull A. Penyakit jantung, Hipertensi dan nutrisi. Dalam: Wendra A, editor (penyunting). Jakarta: PT. Bumi Aksara: 1996.
16. Isezuo SA, Ezunu E. Comparative analysis of lipid profiles among patients with type 2 diabetes melitus, hypertension and concurrent type 2 diabetes and hypertension: a View of Metabolic Syndrome. Journal of The National Medical Association. 2003:328-33.

17. Glaudio G. Correlation between pulse pressure and LDL cholesterol in patients with resistance hypertension. AJH. 2001;4(4):648.

18. Idogun ES, Unuigbe El, Ogunro PS, Akinola OT, Famodu AA. Assessment of serum lipids in Nigerians with type 2 diabetes melitus complications. Journal of Nigerian. 2006.

19. Wahyuni D. Gambaran hipertensi pada Usia 40 tahun ke atas dengan toleransi glukosa terganggu (skripsi). Padang: Universitas Andalas; 2006.

20. Wijaya A. Perbedaan profil lipid antara pasien DM tipe 2 dengan hipertensi dan tanpa hipertensi (skripsi). Surakarta: Universitas Sebelas Maret; 2010. 